\title{
PRDM16 Gene
}

National Cancer Institute

\section{Source}

National Cancer Institute. PRDM16 Gene. NCI Thesaurus. Code C97736.

This gene plays a role in both transcriptional regulation and adipocyte differentiation. 